crops, in an artificial medium. This is something that plant pathologists have spent much energy on for a good many years, never with complete success. Spores from infected plants were placed on a medium containing the combination of minerals first used by Czapek, as well as sucrose, peptone and yeast extract. After one day of incubation at $17^{\circ} \mathrm{C}$ in a moist chamber, germination had occurred and the germ tube had begun to grow. After ten days, a network of fungal growth-a mycelial mat-had developed, and after two to four wceks, stromata bearing uredosopores and occasionally teleutospores-the form in which the fungus overwinters on the host plant-were seen. Previous attempts at culturing this parasite have not succeded in producing the vegetative stage which usually grows within the host tissues, and gives rise to the fruiting bodies. Dr Scott has been able to use the uredospores produced in the culture to infect fresh host plants.

Puccinia graminis was also cultured on a chemically defined medium to obtain some information about the growth rcquirements of the fungus. A medium containing Czapek's minerals together with sucrose and cysteine supported good vegetative growth. Sulphur amino-acids such as cysteine seem to be growth requirements for this fungus. Now that culture of rust fungus has been achieved-Dr Scott's culture has been growing for about three years-the way is clear for further investigations of growth requirements and other physiological features which should lead to a better understanding of the effect of the parasite on the host.

\section{Essential Fatty Acids}

\section{from our Medical Biochemistry Correspondent}

THE poly-unsaturated fatty acids are called essential fatty acids because mammals seem to be unable to form them from mono-unsaturated or from saturated fatty acids. It has often been suggested that the diet of advanced Western countries is deficient in essential fatty acids, and that this deficiency may be the cause of diseases such as cardiovascular disease and multiple sclerosis (Bernsohn and Stephanides, Nature, 215, 821; 1967).

Dr M. A. Crawford has now shown that the proportions of fatty acids in the muscle lipids which are polyunsaturatcd differ very much when animals are living in wild and in domesticated conditicns (Lancet, i, $1336 ;$ 1968). In domestic beef from Britain, only 2 per cent of the fatty acids were poly-unsaturated, while in buffalo meat from East Africa the proportions were 10 per cent in animals living in parkland (which was mainly grassland) and 30 per cent in animals living in natural woodland surroundings. In a survey of different species of wild African animals, the proportion of the fatty acids in the tissue lipids which were poly-unsaturated was between 20 and 40 per cent for those living in woodland or bushland environments. Those living on grassland, like most domestic animals and mar, had only 2-8 per cent of poly-unsaturated fatty acids in their tissue lipids. Preliminary results on the tissue lipids of the heart and aorta showed that these lipids possess the same difference in the proportion of poly-unsaturated fatty acids. The difference seems to depend on the proportion of oil-rich woodland vegetation as opposed to water-rich grass vegetation in the animals' diets. Dr Crawford feels that the proportion of poly-unsaturated fatty acids in the diet may be directly linked with the development of atheroma, because Dr S. Sikes (Proc. Roy. Soc. Med., 61, $160 ; 1968)$ has already shown that elephants living in grassland and scrubland develop calcification and lipid deposits in their arteries which are very similar to human atheroma-a condition which has never been found in the elephants living in their natural habitat of wooded mountains.

In the same spirit, A. J. Sinclair and F. D. Collins (Biochim. Biophys. Acta, 152, 498; 1968) have recently studied the effects of essential fatty acid deficiency on some aspects of lipid metabolism in rats. Rats given only saturated fats develop an accumulation of fat in their livers, but only when fed a saturated fat diet for at least 10 weeks. There is a great increase in the concentration of both triglycerides and phospholipids in the liver. Although the rate of secretion of triglycerides to the plasma from the liver is increased, the deficient animals have lower plasma concentrations of triglycerides and phospholipids. The rate of synthesis of fatty acids in the liver is not significantly altered, but the serum concentration of free fatty acids is considerably increased. When the serum lipoproteins are separated in the ultracentrifuge, the very low density lipoproteins are decreased in quantity and there is less triglyceride and phospholipid per unit of protein in this fraction. Other agents causing fatty livers act much more rapidly, usually, it is thought, by decreasing the synthesis of very low density lipoproteins. The authors consider that the decrease in very low density lipoproteins in essential fatty acid deficiency is not enough to account for the development of fatty liver on its own. There are obviously great changes in fat metabolism in the complete absence of poly-unsaturated fatty acids, and the long-term effect of a relative deficiency may be of great importance.

\section{Bacteria without DNA}

\section{from our Cell Biology Correspondent}

Hirota and his colleagues lament, in the current issue of the Journal of Molecular Biology (35, 175; 1968), that if only bacteria without DNA had been discovered ten years ago, they would have been a splendid tool for studying problems which, today, are understood. No doubt Adler and his colleagues (Adler, Fisher, Cohen and Hardigree, Proc. US Nat. Acad. Sci., 5\%, 321 ; 1967) felt the same when they discovered minicells last year but such is the pace of discovery that most of the properties of these cells have been precisely predicted.

Hirota et al. have obtained their cells without DNA from a temperature sensitive double mutant, strain CRT46, of $E$. coli $K 12$ which, at $40^{\circ} \mathrm{C}$, lacks the ability to synthesize DNA but can still form cross-walls or septa. The mutation which halts DNA synthesis apparently affects chromosomal DNA replication specifically; phage and sex factors replicate at $40^{\circ} \mathrm{C}$. The cells without DNA are produced at $40^{\circ} \mathrm{C}$ as septa split off non-nucleated cytoplasm from the parental cell thus forming a multicellular filament with nucleated cells in the centre and non-nucleated cells on either side. No DNA can be seen in the light and electron microscopes in the non-nucleated cells, and, as autoradiography shows, they fail to incorporate thymidine. Apart from this, the fine structure of the cell without DNA is similar to that of normal cells. 